\title{
ANALISIS KINERJA KEUANGAN PERUSAHAAN KOSMETIK YANG TERCATAT DI BEI TAHUN 2021
}

\author{
Nur Annisa Nurdin, [Dr. Rosnaini Daga, S.E., M.M.] \\ Institut Bisnis dan Keuangan Nitro
}

Nurannisanurdin1605@gmail.com, [rosnaini.daga@nitromks.ac.id]

\begin{abstract}
Abstrak
Penelitian ini berjudul Analisis Kinerja Keuangan Perusahaan Kosmetik Yang Tercatat Di Bei Tahun 2021. Penelitian ini bertujuan untuk mengetahui, memprediksi dan menganalisis kinerja keuangan dengan menggunakan rasio-rasio keuangan: 1.) Rasio Likuiditas, 2.) Rasio Solvabilitas, 3.) Rasio Profitabilitas, dan 4.) Rasio Aktivitas. Metode analisis yang digunakan dalam penelitian ini adalah deskriptif komparatif.

Hasil penelitian ini menunjukkan bahwa kondisi keuangan PT. Mustika Ratu Tbk dan PT. Martina Berto Tbk tahun 2021 cukup baik. Analisis rasio likuiditas pada perusahaan PT Mustika Ratu Tbk dan PT. Martina Berto Tbk menunjukan perusahaan berada dalam kondisi yang cukup baik, karena rasio yang diperoleh kebanyakan berada diatas standar rata-rata rasio likuiditas. Dalam keadaan ini perusahaan mampu memenuhi kewajiban jangka pendeknya tanpa harus menjual sebagian akun yang ada pada aktiva lancar bila hendak melunasi hutang lancarnya. Analsis rasio solvabilitas PT Mustika Ratu Tbk dengan menggunakan rasio DAR dan DER menunjukan bahwa perusahaan berada dalam kondisi yang baik, karena rasio yang diperoleh tidak melebihi standar rata-rata rasio solvabilitas. Sehingga tidak menyebabkan resiko kerugian yang besar. Dari rasio profitabilitas yaitu menggunakan rumus seperti: gross profit margin, net profit margin, return on assets dan return on equity. Kedua perusahaan mengalami penurunan keuntungan (inprofit), dalam perhitungan net profit margin, return on assets dan return on equity yang tidak memenuhi standar rata-rata industri, kecuali dalam perhitungan gross profit margin kedua perusahan di atas rata-rata industri. Tetapi, hasil perhitungan rata-rata dari kedua perusahaan PT. Martina Berto Tbk lebih baik dari pesaingnya yaitu PT. Mustika Ratu Tbk.
\end{abstract}

Kata kunci: Kinerja Keuangan, Rasio Keuangan, Kosmetik.

\section{PENDAHULUAN}

\section{A. Latar Belakang}

Perkembangan dunia usaha dapat tercermin dari laporan keuangan yang dibuat oleh manajemen perusahaan, persaingan antara satu perusahaan dengan perusahaan lainnya semakin ketat, belum lagi kondisi perekonomian yang tidak menentu 
menyebabkan banyak perusahaan yang tiba-tiba mengalami kebangkrutan, oleh karena itu agar perusahaan dapat bertahan atau bahkan bisa tumbuh dan berkembang perusahaan harus mencermati kondisi dan kinerja perusahaan. Pengukuran aktivitas kinerja perusahaan dirancang untuk menaksir bagaimana aktivitas kinerja dan hasil akhir yang dicapai menurut (Sucipto, 2012).

Perusahaan merupakan salah satu pokok kegiatan perekonomian yang hidup dalam lingkungan dunia usahayang berubah secara cepat dan dinamis. Seiring dengan pertumbuhan ekonomi di era globalisasi yang cukup pesat, menuntut perusahaan untuk melakukan pengelolaan usaha yang lebih baik. Masing-masing perusahaan dituntut untuk bekerja lebih efektif dan efisien khususnya untuk meningkatkan prestasi perusahaan dalam kinerja keuangannya baik untuk jangka pendek maupun jangka panjang. Salah satu tujuan utama didirikannya perusahaan adalah untuk memperoleh keuntungan yang maksimal. Namun berhasil tidaknya perusahaan dalam mencari keuntungan dan mempertahankan perusahaannya tergantung pada manajemen keuangan. Perusahaan harus memiliki kinerja keuangan yang sehat dan efisien untuk mendapatkan keuntungan atau laba.

Di samping itu, demi tercapainya tujuan perusahaan yang paling utama adalah perusahaan harus mampu mengatur posisis keuangannya. Posisi keuangan tersebut berfungsi sebagai tolak ukur kinerja keuangan perusahaan yang digunakan untuk mengetahui ada atau tidaknya kemajuan di dalam perusahaan. Hal ini akan mempengaruhi keberlangsungan perusahaan untuk maju dan kerjasama antara perusahaan yang satu dengan perusahaan yang lain. Salah satu faktor yang dapat menunjukkan bagaimana kinerja perusahaan itu baik atau tidak yaitu dengan analisis laporan keuangan.

Analisis laporan keuangan menggunakan perhitungan rasio-rasio agar dapat mengevaluasi keadaan finansial perusahaan dimasa lalu, sekarang dan masa yang akan datang. Rasio dapat dihitung berdasarkan sumber datanya yang terdiri dari rasio-rasio neraca yaitu rasio yang disusun dari data yang berasal dari data neraca dan laporan laba rugi. Laporan keuangan perlu disusun untuk mengetahui apakah kinerja perusahaan tersebut meningkat atau bahkan menurun dan di dalam menganalisis laporan keuangan diperlukan alat analisis keuangan, salah satunya adalah dengan menggunkan rasio-rasio keuangan. Rasio keuangan tersebut meliputi rasio likuiditas, rasio solvabilitas, rasio aktivitas, rasio profitabilitas.

Kinerja keuangan perusahaan merupakan tingkat prestasi (kerja) hasil nyata yang kadang-kadang digunakan untuk tercapainya hasil positif atau hasil dari banyak keputusan yang dibuat secara terus-menerus oleh manajemen untuk mencapai tujuan tertentu secara efektif dan efisien, (Djarwanto, 2008: 19). Kinerja keuangan adalah gambaran untuk mengetahui sudah sampai mana suatu perusahaan telah melakukan aturan pelaksaan keuangan dengan baik dan benar. Kinerja perusahaan adalah kemampuan sebuah perusahaan untuk mengelola sumber daya guna nya agar mengetahui kondisi keuangan suatu perusahaan apakah baik atau buruk, disamping itu kinerja perusahaan juga berguna untuk melihat prestasi kerja dalam periode tertentu (Irhan Fahmi 2011:2). Analisis Rasio keuangan merupakan teknik analisis yang digunakan untuk mengetahui kondisi keuangan suatu perusahaan dalam periode 
tertentu, ataupun hasil-hasil usaha dari suatu perusahaan pada satu periode tertentu dengan cara membandingkan angka-angka yang ada dalam laporan keuangan (Irawati 2005: 22).Kemampuan perusahaan dalam menjalankan usahanya yang secara financial ditunjukkan dalam laporan keuangan. Laporan keuangan disusun dan disajikan dengan maksud untuk memberikan informasi kuantitatif mengenai keadaan keuangan pada periode tertentu.

PT. Unilever,Tbk, PT. Mustika Ratu, Tbk, PT. Martina Berto,Tbk, PT. Mandom Indonesia, Tbk adalah perusahaan kosmetik dan perlengkapan rumah tangga yang brand produknya sangat dikenal masyarakat antara lain brand ponds, pepsodent, dan lain-lain. Dengan perusahaan sebesar ini dengan produk-produknya yang menjadi market leader, ada kemungkinan bahwa kinerja keuangan perusahaannya juga baik.Penilaian kinerja merupakan metode untuk mengawasi kegiatan operasi perusahaan. Metode penilaian kinerja tersebut dapat membantu pihak manajemen dalam mengambil keputusan sesuai tujuan yang telah ditetapkan sejak semula serta berperan dalam menentukan strategi apa yang akan diambil perusahaan.

Dua perusahaan besar PT. Mustika Ratu Tbk dan PT. Martina Berto Tbk merupakan penguasa pasar kosmetik yang keberadaannya mampu bersaing sampai saat ini. Kedua perusahaan tersebut menjadi pesaing bagi produk-produk kosmetik asing yang masuk ke Indonesia. Selain bersaing dalam hal memproduksi kosmetik dan jamu, kedua penguasa kosmetik tersebut sama-sama mensponsori acara besar di Indonesia. PT. Mustika Ratu sebagai sponsorship dalam ajang Puteri Indonesia dan PT. Martina Berto sebagai sponsorhip dalam ajang Miss Indonesia. "Dua perusahaan produk kecantikan PT. Mustika Ratu Tbk (MRAT) dan PT. Martina Berto Tbk (MBTO) makin ekspansif membuka gerai di luar negeri. Pasar yang dituju yaitu Malaysia, Singapura, Ceko, Kanada, Bulgaria dan Jepang.

Penilaian kinerja suatu perusahaan mempunyai arti yang sangat penting dalam menentukan sasaran investasi modal yang dimilikinya. Mengingat pentingnya laporan keuangan dalam memberikan informasi kepada pihak-pihak yang berkepentingan, maka laporan keuangan harus bersifat menyeluruh dan mencakup kepentingan semua orang (pemilik perusahaan, manajemen, investor, kreditur, pemerintah, karyawan, serta pihakpihak lainnya). Oleh karena itu, kinerja perusahaan sangat ditentukan oleh kualitas kebijaksanaan manajemen yang diambil, maka untuk menilai kinerja keuangan perusahaan perlu melakukan analisis laporan keuangan.

\section{TUJUAN PUSTAKA}

\section{Kosmetik}

Kosmetik berarti alat-alat kecantikan seperti bedak, kream, lotion, dan lainlain untuk memperindah wajah, kulit dan sebagainya. Kosmetik berasal dari kata kosmein (Yunani) yang berarti "berhias". Kosmetik sudah dikenal orang sejak zaman dahulu kala. Di Mesir, 3500 tahun Sebelum Masehi telah digunakan berbagai bahan alami baik yang berasal dari tumbuh-tumbuhan, hewan maupun bahan alam lain 
misalnya tanah liat, lumpur, arang, batubara bahkan api, air, embun, pasir, atau sinar matahari (Tranggono, 2007)

Penggolongan kosmetik berdasarkan penggunaannya menurut Peraturan Menteri Kesehatan RI Nomor : 045/C/SK/1977 tanggal 22 Januari 1977 dibagi menjadi 13 kelompok, yaitu preparat untuk bayi, misalnya minyak bayi, bedak bayi, preparat untuk mandi, misalnya sabun mandi, bath capsule, preparat untuk mata, misalnya mascara, eye shadow, preparat untuk wangi-wangian, misalnya parfum, toilet water, preparat untuk rambut, misalnya cat rambut, hair spray, preparat pewarna rambut, misalnya cat rambut, preparat make up (kecuali mata), misalnya bedak, lipstik, preparat untuk kebersihan mulut, misalnya pasta gigi, mouth washes, preparat untuk kebersihan badan, misalnya deodorant, preparat kuku, misalnya cat kuku, losion kuku, preparat perawatan kulit, misalnya pembersih, pelembab pelindung, preparat cukur, misalnya sabun cukur, preparat untuk suntan dan sunscreen, misalnya sunscreen foundation.

\section{Manajemen Keuangan}

\section{a. Pengertian Manajemen Keuangan}

Menurut JF Bradley manajemen keuangan adalah bidang manajemen bisnis yang ditujukan untuk penggunaan model secara bijaksana \&seleksi yang seksama dari sumber modal untuk memungkinkan unit pengeluaran untuk bergerak ke arah mencapai tujuannya

Menurut Sutrisno manajemen keuangan adalah Sebagai semua aktivitas perusahaan dengan usaha-usaha mendapatkan dana perusahaan dengan biaya yang murah serta usaha untuk menggunakan dan mengalokasikan dana tersebut secara efisien. (2003:3)

Menurut Liefman manajemen keuangan merupakan usaha untuk menyediakan uang dan menggunakan uang untuk mendapat atau memperoleh aktiva. Menurut Erlina, manajemen keuangan merupakan manajemen terhadap fungsi-fungsi keuangan. Fungsi-fungsi keuangan tersebut meliputi bagaimana memperoleh dana (raising of fund) dan bagaimana menggunakan dana tersebut (allocation of fund)

\section{b. Tujuan Manajemen Keuangan}

Menurut Sutrisno (2009) Tujuan manajemen keuangan adalah meningkatkan kemakmuran para pemegang saham atau pemilik. Kemakmuran para pemegang saham diperlihatkan dalam wujud semakin tingginya harga saham. Menurut Lontoh, Frederich \& Lindrawati, Jurnal Widia Manajemen \& Akuntansi (2004) Tujuan manajemen keuangan adalah memaksimumkan nilai perusahaan. Memaksimumkan nilai bermakna lebih luas dan lebih umum daripada memaksimumkan laba

\section{c. Fungsi Manajemen Keuangan}

Fungsi Manajemen Keuangan adalah:

a. Perencanaan Keuangan yaitu membuat rencana pemasukan dan pengeluaraan serta kegiatan-kegiatan lainnya untuk periode tertentu.

b. Penganggaran Keuangan yaitu tindak lanjut dari perencanaan keuangan dengan membuat detail pengeluaran dan pemasukan. 
c. Pengelolaan Keuangan yaitu menggunakan dana perusahaan untuk memaksimalkan dana yang ada dengan berbagai cara.

d. Pencarian Keuangan yaitu mencari dan mengeksploitasi sumber dana yang ada untuk operasional kegiatan perusahaan.

e. Penyimpanan Keuangan yaitu mengumpulkan dana perusahaan serta menyimpan dana tersebut dengan aman.

f. Pengendalian Keuangan yaitu melakukan evaluasi serta perbaikan atas keuangan dan sistem keuangan pada perusahaan.

g. Pemeriksaan Keuangan yaitu melakukan audit internal atas keuangan perusahaan yang ada agar tidak terjadi penyimpangan

Sedangkan menurut Sutrisno (2009) fungsi manajemen keuangan terdiri dari tiga keputusan utama yang harus dilakukan oleh suatu perusahaan: keputusan investasi, keputusan pendanaan, dan keputusan deviden. Masing-masing keputusan harus berorientasi pada pencapaian tujuan perusahaan. Kombinasi dari ketiganya akan memaksimumkan nilai perusahaan

\section{Laporan Keuangan}

\section{a. Pengertian Laporan Keuangan}

Setelah data transaksi dicatat ke dalam jurnal dan diposting ke dalam buku besar (ledger), laporan akuntansi disiapkan untuk memberikan informasi yang berguna bagi para pemakai laporan (users), terutama sebagai dasar pertimbangan dalam proses pengambilan keputusan kelak. Laporan akuntansi ini dinamakan laporan keuangan. Tujuan Khusus Laporan Keuangan adalah menyajikan secara wajar dan sesuai dengan prinsip akuntansi yang berlaku umum mengenai posisi keuangan, hasil usaha, dan perubahan lain dalam posisi keuangan.

Laporan keuangan adalah informasi yang diperlukan sebagai salah satu komunikasi keuangan kepada pihak-pihak yang berkepentingan dengan menggambarkan kondisi keuangan dan kinerja perusahaan biasanya dalam bertuk neraca, laporan laba rugi dan laporan arus kas serta laporan ekuitas pemilik atau pemegang saham. Kinerja perusahaan adalah prestasi yang dicapai perusahaan dalam periode tertentu sebagai hasil dari proses kerja selama periode tersebut. (Harto Limbong, dkk).

Menurut Hery (2012), Laporan keuangan adalah hasil dari proses akuntansi yang dapat digunakan sebagai alat untuk mengkomunikasikan data keuangan atau aktivitas perusahaan kepada pihak-pihak yang berkepentingan. Dengan kata lain sebagai alat informasi yang menghubungkan perusahaan dengan pihak-pihak yang berkepentingan, yang menunjukkan kondisi kesehatan keuangan perusahaan dan kinerja perusahaan.

Menurut Kasmir (2015), Laporan keuangan adalah laporan yang menunjukkan kondisi keuangan perusahaan pada saat ini atau dalam suatu periode tertentu.

Maka dapat disimpulkan laporan keuangan adalah hasil dari proses akuntansi yang dapat digunakan sebagai alat untuk mengkomunikasikan data keuangan atau aktivitas perusahaan kepada pihak-pihak yang berkepentingan 


\section{b. Tujuan Laporan Keuangan}

Menurut Kasmir (2008), tujuan pembuatan atau penyusunan laporan keuangan yaitu:

1. Memberikan suatu informasi perihal jenis dan jumlah aktiva (harta) yang dimiliki oleh perusahaan pada saat ini.

2. Memberikan informasi perihal jenis dan jumlah kewajiban dan modal yang dimiliki oleh perusahaan pada saat ini.

3. Memberikan informasi perihal jenis dan jumlah pendapatan yang diperoleh pada suatu periode tertentu perusahaan.

4. Memberikan informasi perihal jumlah biaya dan jenis biaya yang dikeluarkan perusahaan dalam suatu periode tertentu.

5. Memberikan informasi perihal perubahan-perubahan yang terjadi terhadap aktiva, pasiva, dan modal perusahaan

6. Memberikan informasi perihal kinerja manajemen perusahaan dalam periode akuntansi.

7. Memberikan informasi tentang catatan-catatan atas laporan keuangan.

8. Untuk Informasi keuangan lainnya.

\section{c. Jenis Laporan Keuangan}

Menurut Kasmir (2016), secara umum ada lima macam jenis laporan keuangan yang biasa disusun:

1. Balance sheet (Neraca)

Balance sheet (neraca) merupakan laporan yang menunjukkan posisi keuangan perusahan pada tanggal tertentu. Arti dari posisi keuangan dimaksudkan adalah posisi jumlah dan jenis aktivitas (harta) dan passiva (kewajiban dan ekuitas) suatu perusahaan.

2. Income Statement (Laporan Laba Rugi)

Income statement (laporan laba rugi) merupakan laporan keuangan yang menggambarkan hasil usaha perusahaan dalam suatu periode tertentu. Dalam laporan laba rugi ini terggambar jumlah pendapatan dan sumbersumber pendapatan yang diperoleh. Kemudian juga tergambar jumlah biaya dan jenis-jenis yang dikeluarkan selama periode tertentu.

3. Laporan Perubahan Modal

Laporan perubahan modal merupakan laporan yang berisi jumlah dan jenis modal yang dimiliki pada saat ini. Kemudian, laporan ini juga menjelaskan perubahan modal dan sebab-sebab terjadinya perubahan modal di perusahaan.

4. Laporan Arus Kas

Laporan arus kas merupakan laporan yang menunjukkan arus kas masuk dan arus kas keluar di perusahaan. Arus kas masuk berupa pendapatan atau pinjaman dari pihak lain, sedangkan arus kas keluar merupakan biaya-biaya yang telah dikeluarkan oleh perusahaan. Baik arus kas masuk maupun arus kas keluar dibuat untuk periode tertentu.

5. Laporan Catatan atas Laporan Keuangan 
Laporan catatan atas laporan keuangan merupakan laporan yang dibuat berkaitan dengan laporan keuangan yang disajikan. Laporan ini memberikan informasi tentang penjelasan yang dianggap perlu atas laporan keuangan yang ada sehingga menjadi jelas sebab penyebabnya. Tujuannya adalah agar pengguna laporan keuangan dapat memahami jelas data keuangan.

Berdasarkan beberapa pengertian diatas, dapat disimpulkan bahwa laporan keuangan memiliki arti tersendiri dalam melihat kondisi keuangan perusahaan tergantung maksud dan tujuan pembuatan laporan keuangan.

\section{d. Pihak-pihak yang Berkepentingan dalam Laporan Keuangan}

Menurut Munawir (2014:2), Laporan keuangan disusun berdasarkan berbagai tujuan. Tujuan utamanya adalah untuk kepentingan pemilik dan manajemen perusahaan serta dapat memberikan informasi kepada berbagai pihakpihak yang sangat berkepentingan terhadap perusahaan itu sendiri. Pihak-pihak yang berkepentingan dalam laporan keuangan adalah sebagai berikut:

a. Pemilik Perusahaan

Laporan keuangan diperlukan oleh pemilik perusahaan untuk menilai hasil-hasil yang telah dicapai, dan untuk menilai kemungkinan hasil-hasil yang akan dicapai dimasa yang akan datang sehingga bisa menaksir bagian keuntungan yang akan diterima dan perkembangan harga saham yang dimilikinya.

b. Manajer atau Pimpinan Perusahaan

Laporan keuangan akan digunakan oleh manajemen untuk:

1. Mengukur tingkat biaya dari berbagai kegiatan usaha.

2. Untuk menentukan atau mengukur efisiensi tiap-tiap bagian, proses atau prduksi serta untuk menentukan derajat keuntungan yang dapat dicapai oleh perusahaan yangbersangkutan.

3. Untuk menilai dan mengukur hasil kerja tiap-tiap individu yang telah diserahi wewenang dan tanggung jawab.

4. Untuk menentukan perlu tidaknya digunakan kebijaksanaan.

c. Para kreditur

Sebelum mengambil keputusan untuk memberi atau menolak permintaan kredit dari suatu perusahaan, perlu mengetahui terlebih dahulu posisi keuangan dan perusahaan yang bersangkutan. Disamping ingin mengukur kemampuan perusahaan untuk membayar hutangnya dan bebanbeban bunganya, juga untuk mengetahui apakah kredit yang akan diberikan itu cukup mendapat jaminan dan perusahaan tersebut, yang digambarkan atau terlihat pada kemampuan perusahaan untuk mendapatkan keuntungan dimasa yang akan datang.

d. Para investor

Para investor berkepentingan terhadap laporan keuangan suatu perusahaan dalam rangka penentuan kebijaksanaan penanaman modalnya, 
apakah perusahaan mempunyai prospek yang cukup baik dan akan diperoleh keuntungan "rate of return" (tingkat pengembalian) yang cukup baik.

e. Pemerintah

Pemerintah dimana perusahaan tersebut berdomisili, sangat berkepentingan dengan laporan keuangan perusahaan tersebut, disamping untuk menentukan besarnya pajak yang harus ditanggung oleh perusahaan juga sangat diperlukan oleh Biro Pusat Statistik, Dinas Perindustrian, Perdagangan dan Tenaga Kerja untuk dasar perencanaan pemerintah

\section{e. Keterbatasan Laporan Keuangan}

Laporan keuangan menggambarkan kondisi secara umum dari perusahaan. Menurut Fahmi (2011) laporan keuangan juga memiliki beberapa keterbatasan yaitu:

1. Laporan keuangan bersifat historis yang merupakan laporan atas kejadian yang telah berlalu, sehingga tidak dapat menjadi satu-satunya sumber informasi dalam proses pengambilan keputusan ekonomi.

2. Laporan keuangan bersifat umum dan bukan dimaksudkan untuk memenuhi kebutuhan pihak tertentu.

3. Proses penyusunan laporan keuangan tidak jauh dari penggunaan taksiran dan berbagai pertimbangan.

4. Akuntansi hanya melaporakan informasi yang material.

5. Laporan keuangan bersifat konservatif dalam menghadapi ketidakpastian.

6. Lebih menekankan pada makna ekonomis suatu peristiwa atau transaksi.

7. Laporan keuangan disusun dengan menggunakan istilah-istilah teknis sehingga pemakai laporan keuangan harus mengerti dan menguasai istilahistilah teknis tersebut.

\section{Kinerja Keuangan}

\section{a. Pengertian Kinerja Keuangan}

Kinerja adalah gambaran pencapaian pelaksanaan suatu kegiatan atau program dalam mewujudkan sasaran, tujuan, misi,dan visi suatu organisasi. Pengukuran kinerja merupakan suatu usaha formal untuk mengevaluasi efisiensi dan efektivitas perusahaan dalam menghasilkan laba dan posisi kas tertentu (Hery, 2015:25). Penilaian kinerja keuangan dilakukan dengan menganalisis laporan keuangan dalam suatu periode atau beberapa periode untuk melihat perkembangan dari perusahaan tersebut.

Menurut Fahmi (2011:239) "kinerja keuangan adalah suatu analisis yang dilakukan untuk melihat sejauh mana suatu perusahaan telah melaksanakan dengan menggunakan aturan-aturan pelaksanaan keuangan secara baik dan benar". Kinerja keuangan dinilai dengan melakukan analisis pada laporan keuangan. Kasmir (2017:69-70) mengemukakan bahwa terdapat dua macam metode analisis laporan keuangan yang biasa dipakai, yaitu analisis vertikal dan analisis horizontal.

Kinerja keuangan adalah gambaran kodisi keuangan perusahaan pada suatu periode tertentu baik menyangkut aspek penghimpunan dana maupun penyaluran 
dana, yang biasanya diukur dengan indikator kecukupan modal, likuiditas, dan profitabilitas (Jumingan, 2006:239).

Kinerja keuangan adalah penilaian tingkat efesiensi dan produktifitas yang dilakukan secara berkala atas dasar laporan manajemen dan laporan keuangan yang merupakan pencerminanan prestasi yang dicapai perusahaan (Tambunan 2007:128).

Menurut Irham Fahmi (2012), Kinerja keuangan adalah suatu analisis yang dilakukan untuk melihat sejauh mana perusahaan telah melaksanakan dengan menggunakan aturan-aturan pelaksanaan keuangan secara baik dan benar.

Menurut Martono dan Harjito (2011), Kinerja keuangan suatu perusahaan sangat bermanfaat bagi berbagai pihak seperti investor, kreditur, analisis, konsultan keuangan, pialang, pemerintah, dan pihak manajemen sendiri.

Pengukuran kinerja digunakan perusahaan untuk melakukan perbaikan diatas kegiatan operasionalnya agar dapat bersaing dengan perusahaan lain. Analisis kinerja keuangan merupakan proses pengkajian secara kritis terhadap review data, menghitung, mengukur, menginterpretasi, dan memberi solusi terhadap keuangan perusahaan pada suatu periode tertentu.

Untuk mengetahui kinerja keuangan perusahaan maka secara umum perlu dilakukan analisis terhadap laporan keuangan, yang menurut Brigham dan Houston (2007:28) mencakup yaitu: pembandingan kinerja perusahaan dengan perusahaan lain dalam industri yang sama dan evaluasi kecenderungan posisi keuangan perusahaan sepanjang waktu. Laporan keuangan perusahaan melaporkan baik posisi perusahaan pada suatu waktu tertentu maupun operasinya selama beberapa periode yang lalu.

Maka dapatd disimpulkan kinerja keuangan adalah proses meninjau data secara ketat, menghitung, mengukur, menjelaskan dan memberikan solusi untuk keuangan perusahaan dalam jangka waktu tertentu.

\section{b. Tujuan Pengukuran Kinerja Keuangan}

Pengukuran kinerja perusahaan dapat digunakan untuk meningkatkan operasionalnya agar dapat bersaing dengan perusahaan lain. Menurut Munawir (2012) menyatakan bahwa, tujuan dari pengukuran kinerja keuangan perusahaan adalah:

1. Mengetahui tingkat likuiditas Likuiditas menunjukkan kemampuan suatu perusahaan untuk memenuhi kewajiban keuangan yang harus segera diselesaikan pada saat ditagih.

2. Mengetahui tingkat solvabilitas Solvabilitas menunjukkan kemampuan perusahaan untuk memenuhi kewajiban keuangannya apabia perusahaan tersebut di likuidasi, baik keuangan jangka pendek maupun jangka panjang.

3. Mengetahui tingkat rentabilitas Rentabilitas atau yang sering disebut dengan profitabilitas menunjukkan kemampuan perusahaan untuk menghasilkan laba selama periode tertentu.

4. Mengetahui tingkat stabilitas Stabilitas menunjukkan kemampuan perusahaan untuk melakukan usahanya dengan stabil, yang diukur dengan mempertimbangkan kemampuan perusahaan untuk membayar hutang- 
hutangnya serta membayar beban bunga atas hutang-hutangnya tepat pada waktunya.

Dengan demikian dapat disimpulkan bahwa pengukuran kinerja keuangan memberikan penilaian atas pengelolaan aset perusahaan oleh manajemen dan manajemen perusahaan dituntut untuk melakukan evaluasi dan tindakan perbaikan atas kinerja keuangan perusahaan yang tidak sehat.

\section{c. Pengukuran Kinerja}

Menurut rudianto (2013:189) merupakan hasil atau prestasi yang telah dicapai oleh manajemen perusahaan dalam menjalankan fungsinya mengelola aset perusahaan secara efektif selama periode tertentu. Kinerja keuangan sangat dibutuhkan oleh perusahaan untuk mengetahui dan mengevaluasi sampai di mana tingkat keberhasilan perusahaan berdasarkan aktivitas keuangan yang telah dilaksanakan. Menilai kinerja baik atau tidak dalam pelaksanaannya harus ada suatu ukuran yang dapat dijadikan perbandingan. Ukuran perbandingan untuk metode time series yang biasa dipakai adalah kinerja keuangan sebelumnya, sedangkan dalam metode cross section untuk mengukur tingkat kesehatan perusahaan. Salah satu cara yang dapat dipakai untuk dapat mengukur kinerja keuangan tersebut adalah analisis rasio keuangan, dimana data pokok yang digunakan dalam analisis ini adalah laporan keuangan perusahaan yang berupa neraca dan laporan laba rugi perusahaan.

Menurut Syamsuddin (2011:39) ada dua cara yang dapat dilakukan di dalam membandingkan rasio finansial perusahaan, yaitu Cross-sectional approach dan Time series analysis.

1) Cross-sectional approach

Suatu cara mengevaluasi dengan jalan membandingkan ratio-ratio antara perusahaan yang satu dengan perusahaan lainnya yang sejenis pada saat yang bersamaan. Jadi dengan pendekatan ini dimaksudkan untuk mengetahui seberapa baik atau buruk suatu perusahaan dibandingkan dengan perusahaan sejenis lainnya.

2) Time series analysis

Dilakukan dengan jalan membandingkan ratioratio finansial perusahaan dari satu periode ke periode lainnya. Pembandingan antara ratio yang dicapai saat ini dengan ratio-ratio pada masa lalu akan memperlihatkan apakah perusahaan mengalami kemajuan atau kemunduran. Perkembangan perusahaan akan dapat dilihat pada tren dari tahun ke tahun, sehingga dengan melihatperkembangan ini perusahaan dapat membuat rencana-rencana untuk masa depannya

\section{Analisis Laporan Keuangan}

\section{a. Pengertian Analisis Laporan Keuangan}

Menurut Prastowo (2015:50) Analisis Laporan Keuangan merupakan proses yang penuh pertimbangan dalam rangka membantu mengevaluasi posisi keuangan dan hasil operasi perusahaan pada masa lalu dan masa sekarang, dengan tujuan untuk menentukan estimasi dan prediksi yang paling mungkin mengenai kondisi 
keuangan dan kinerja perusahaan di masa yang akan datang. Analisis terhadap laporan keuangan suatu perusahaan pada dasarnya karena ingin mengetahui tingkat profitabilitas (keuntungan) dan tingkat risiko atau tingkat kesehatan suatu perusahaan. Pekerjaan yang paling mudah dalam analisis keuangan tentu saja menghitung rasio-rasio keuangan suatu perusahaan.

\section{b. Metode Analisis Laporan Keuangan}

Dalam praktiknya terdapat dua macam metode analisis laporan keuangan yang biasa dipakai, yaitu metode vertikal (statis) dan metode horizontal (dinamis) (Kasmir, 2015:69).

1. Teknik analisis vertikal yang digunakan adalah teknik analisis persentase per komponen yang dilakukan dengan menhitung persentase dari masing-masing unsur/komponen aset, liabilitas dan ekuitas terhadap total aset, liabilitas dan ekuitas, serta masing-masing unsur laba rugi terhadap total penjualannya. Berikut rumus persentase per komponen:

$$
\text { Persentase per komponen }=\frac{\text { masing masing saldo pos }}{\text { total kelompok pos } / \text { komponen }} \times 100 \%
$$

2. Teknik analisis horizontal yang digunakan adalah teknik analisis perbandingan. Indikator analisis perbandingan yaitu jumlah nominal perubahan dan persentase (\%) perubahannya. Berikut rumus analisis perbandingan:

$$
\text { Persentase perubahan }=\frac{\text { saldo pos pos tahun berjalan }}{\text { saldo pos pos tahun sebelumnya }} \times 100 \%
$$

\section{c. Teknik Analisis Laporan Keuangan}

Subramanyam dan Wild (2012:30) mengungkapkan bahwa teknik analisis laporan keuangan diantaranya yaitu:

1. Analisis laporan keuangan komperatif yang dilakukan dengan cara menelah neraca, daftar laba rugi, atau daftar arus kas yang berurutan dari satu periode ke periode berikutnya.

2. Analisis laporan keuangan common-size yaitu menyajikan laporan keuangan dalam bentuk persentase yang dikaitkan dengan suatu jumlah yang dinilai penting misalnya pos-pos neraca terhadap jumlah aktiva atau penjualan untuk laba rugi.

3. Analisis rasio yaitu membandingkan antara pos-pos tertentu dengan pos lain yang memiliki hubungan ekonomis.

4. Analisis arus kas yaitu menggunakan daftar arus kas untuk melakukan evaluasi sumber dan penggunaan dana atau kas.

5. Penilaian yang biasanya didasarkan pada nilai intrinsik sebuah perusahaan atau sahamnya.

\section{Analisis Rasio Keuangan}

a. Pengertian Rasio Keuangan 
Menurut Munawir (2007: 64), analisis rasio adalah suatu rasio yang menggambarkan suatu hubungan atau perbandingan jumlah tertentu dengan jumlah lainnya menggunakan alat analisis berupa rasio yang dapat menjelaskan kepada penganalisa tentang baik atau buruknya posisi keuangan perusahaan terutama jika angka rasio pembanding yang digunakan sebagai standart.

Menurut Kasmir (2010) rasio keuangan adalah indeks yang menghubungkan dua angka akuntansi dan diperoleh dengan membagi satu angka dengan angka lainnya. Rasio keuangan digunakan untuk men Dalam analisis rasio keuangan, hasil analisisnya dinyatakan dalam bentuk rasio yang merupakan perbandingan antara suatu rekening tertentu dalam laporan keuangan dengan rekening lainnya.

\section{b. Manfaat Analisis Rasio Keuangan}

Menurut Fahmi (2014:109), menyatakan bahwa dengan menggunakan rasio keuangan sebagai alat analisis dapat diperoleh manfaat yaitu:

a. Analisis rasio keuangan sangat bermanfaat untuk dijadikan sebagai alat untuk menilai kinerja dan prestasi perusahaan.

b. Analisis rasio keuangan sangat bermanfaat bagi pihak manajemen sebagai rujukan untuk membuat perencanaan.

c. Analisis rasio keuangan dapat dijadikan sebagai alat untuk mengevaluasi kondisi suatu perusahaan dari perspektif keuangan.

d. Analisis rasio keuangan juga bermanfaat bagi para kreditor dapat digunakan untuk memperkirakan potensi risiko yang akan dihadapi dikaitkan dengan adanya jaminan kelangsungan pembayaran bunga dan pengembalian pokok pinjaman.

e. Analisis rasio keuangan dapat dijadikan sebagai penilaian bagi pihak stakeholder organisasi.

\section{c. Jenis-Jenis Rasio Keuangan}

Untuk mengukur kinerja keuangan menggunakan rasio keuangan, maka jenis-jenis rasio keuangan perusahaan adalah sebagai berikut:

1) Profitability Ratio

Profitabilitas adalah rasio yang mengevaluasi kemampuan perusahaan dalam mencari keuntungan. Rasio ini juga dapat mengukur efektivitas manajemen perusahaan. Rasio ini erat kaitannya dengan kelangsungan hidup perusahaan (Huzari, 2020). Rasio ini erat kaitannya dengan kelangsungan hidup perusahaan. Rasio yang digunakan untuk mengetahui profitabilitas perusahaan dalam penelitian ini adalah return on asset.

2) Liquidity Ratio

Rasio lancar adalah ukuran bagaimana perusahaan membayar hutang jangka pendeknya (Peranginangin \& Manurung, 2020).

3) Solvability Ratio

Solvability ratio adalah rasio yang menunjukkan kemampuan suatu perusahaan dalam memenuhi kewajiban dengan dibiayai melalui hutang. Perusahaan yang memiliki kekayaan atau aktiva yang cukup untuk membayar semua hutanghutangnya disebut perusahaan yang solvable 
4) Activity Ratio

Rasio Aktivitas adalah rasio yang menggambarkan sejauh mana suatu perusahaan mengukur efektivitas menggunakan aktiva yang dimilikinya (Huzari, 2020). Rasio ini digunakan untuk mengetahui kemampuan dana yang tertanam dalam keseluruhan aktivitas yang berputar pada suatu periode tertentu.

Menurut Toto Prihadi (2012), membagi rasio keuangan menjadi lima jenis yang berbeda, yaitu : Rasio Likuiditas, Rasio Aktivitas, Rasio Profitabilitas, Rasio Solvabilitas, dan Rasio Ukuran Pasar. Rasio Likuiditas adalah rasio untuk mengukur kemampuan perusahaan dalam memenuhi kewajiban jangka pendek. Rasio Aktivitas adalah rasio untuk mengukur efektivitas perusahaan dalam memutar dana. Rasio Profitabilitas adalah rasio untuk mengukur kemampuan perusahaan dalam menghasilkan keuntungan atau laba. Rasio Solvabilitas adalah rasio untuk mengukur kemampuan perusahaan dalam memenuhi seluruh kewajiban, baik kewajiban jangka pendek maupun jangka panjang. Rasio Ukuran Pasar adalah rasio yang mengkaitkan antara kondisi internal perusahaan dengan persepsi pasar.

\section{Penelitian Terdahulu}

Penelitian ini mengacu pada penelitian yang pernah dilakukan oleh beberapa peneliti terdahulu, ialah:

1. Retno Tri Setyowati (2008) meneliti tentang analisis rasio keuangan untuk menilai kinerja perusahaan consumer goods. Analisis yang digunakan yaitu rasio likuiditas, rasio aktivitas dan rasio profitabilitas. Penelitian tersebut menyimpulkan bahwa analisis rasio keuangan yang telah dilakukan menunjukkan bahwa kinerja perusahaan selama tahun 2005-2008 menunjukkan tingkat kinerja perusahaan yang sehat sekali.

2. Astrinika linda agustin, Darminto, Dan Siti Ragil Handayani (2011) meneliti tentang analisis rasio keuangan untuk menilai kinerja perusahaan semen yang terdaftar di BEI selama tahun 2009-2011 Penelitian tersebut menyimpulkan Berdasarkan nilai rata-rata rasio likuiditas, rasio aktivitas, rasio leverage, rasio profitabilitas, dan rasio pasar PT. Semen Gresik (Persero) Tbk, PT. Holcim Indonesia Tbk dan PT. Indocement Tunggal Prakarsa yang mempunyai nilai kinerja keuangan sehat adalah PT. Semen Gresik (Persero) Tbk dan PT. Indocement Tunggal Prakarsa Tbk

3. Monalisa Anggriyani Br. Girsang (2020) meneliti tentang Analisis Kinerja Keuangan Berdasarkan Metode Vertikalhorizontal Pada Perusahaan Kosmetik Dan Barang Keperluan Rumah Tangga Yang Terdaftar Di Bursa Efek Indonesia. Penelitian tersebut menyimpulkan bahwa berdasarkan analisis metode vertikal dan horizontal pada laporan keuangan perusahaan kosmetik dan barang keperluan rumah tangga yang terdaftar di Bursa Efek Indonesia, pada laporan posisi keuangan sudah baik dan menunjukkan pergerakkan positif, sedangkan pada laporan laba rugi ada beberapa perusahaan yang masih kurang baik dan menunjukkan kecenderungan negative 
4. Putri Yulia Christian (2015) meneliti tentang Analisis Rasio Keuangan Untuk Menilai Kinerja Keuangan pada Perusahaan Kosmetik di BEI. Hasil pengujian menunjukkan kinerja tingkat likuiditas dan solvabilitas perusahaan PT Mandom Indonesia, Tbk masih lebih baik dibandingkan dengan perusahaan kosmetik lainnya, Kinerja keuangan ditinjau dari tingkat profitabilitas dan aktivitas menunjukkan PT Unilever, Tbk memiliki kinerja lebih baik dibandingkan perusahaan kosmetik lainnya. Dari hasil analisis rasio keuangan terlihat PT Unilever, Tbk memiliki kinerja keuangan yang lebih baik dibandingkan dengan ketiga perusahaan kosmetik lainnya. Hal ini diindikasikan dari sembilan rasio indikator lima diantaranya menunjukkan kinerja yang baik.

5. Puput Anggrenia dan Harlendro (2016) meneliti tentang Analisis Rasio Keuangan Untuk Menilai Kinerja Keuangan Perusahaan Kosmetik dan Barang Keperluan Rumah Tangga yang Terdaftar di BEI Periode 2009-2013. Hasil penelitian menunjukkan bahwa PT. Unilever Indonesia Tbk memiliki profitabilitas dan pertumbuhan penjualan serta laba bersih yang baik bila dibandingkan dengan PT. Mustika Ratu Tbk dan juga PT. Mandom Indonesia Tbk. Sementara dalam hal leverage dan likuiditasnya, PT. Mustika Ratu Tbk memiliki kinerja yang lebih bagus jika dibandingkan dengan PT. Mandom Indonesia Tbk dan juga PT. Unilever Indonesia Tbk.

\section{METODOLOGI PENELITIAN}

\section{A. LOKASI DAN WAKTU PENELITIAN}

Penelitian ini dilaksanakan di PT. Bursa Efek Indonesia yang beralamatkan Jl. DR. Ratulangi, Mario, Kota Makassar, Sulawesi Selatan dengan jangka waktu penelitian selama kurang lebih 1 (satu) bulan.

\section{B. JENIS DAN SUMBER DATA}

\section{Jenis Data}

Jenis data yang digunakan dalam penelitian ini berupa data kuantitatif, yaitu data berupa laporan keuangan PT Bursa efek Indonesia tahun 2020-2021.

2. Sumber Data

Dalam penelitian ini, data yang digunakan bersumber dari data sekunder berupa data keuangan yang kuantitatif dan juga diperoleh dari beberapa jurnal pendukung yang berkaitan dengan judul penulis serta referensi-referensi lainnya.

\section{TEKNIK PENGUMPULAN DATA}

Untuk memperoleh data yang diperlukan, penulis menggunakan metode pengumpulan data sebagai berikut:

1. Penelitian Kepustakaan (Library Research)

Jenis penelitan kepustakaan (library research), yaitu serangkaian penelitian yang berkenaan dengan metode pengumpulan data pustaka, atau penelitian yang obyek penelitiannya digali melalui beragam informasi kepustakaan (buku, ensiklopedi, jurnal ilmiah, koran, majalah, dan dokumen). Penelitian kepustakaan 
atau kajian literatur (literature review, literature research) merupakan penelitian yang mengkaji atau meninjau secara kritis pengetahuan, gagasan, atau temuan yang terdapat di dalam tubuh literatur berorientasi akademik (academic-oriented literature), serta merumuskan kontribusi teoritis dan metodologisnya untuk topik tertentu. Fokus penelitian kepustakaan adalah menemukan berbagai teori, hukum, dalil, prinsip, atau gagasan yang digunakan untuk menganalisis dan memecahkan pertanyaan penelitian yang dirumuskan

2. Penelitian Dokumentasi (Documentation Research)

Menurut Suharsimi Arikunto (2006: 141) "Metode dokumentasi adalah mencari data atau variabel yang berupa catatan, transkip, buku-buku, surat kabar, majalah, prasasti, notulen, agenda, dan sebagainya". Dalam penelitian ini data dokumentasi yang penulis kumpulkan adalah untuk memperoleh data laporan keuangan PT. Mustika Ratu Tbk dan PT. Martina Berto Tbk Rasio Profitabilitas dan dokumentasi-dokumentasi yang berkaitan dengan penelitian.

\section{POPULASI DAN SAMPEL}

1. Populasi

Populasi yang digunakan dalam penelitian ini adalah data laporan keuangan PT. Mustika Ratu Tbk dan PT. Martina Berto Tbk Rasio Profitabilitas 2021.

2. Sampel

Sampel yang digunakan dalam penelitian ini adalah sampel jenuh, dimana semua populasi dijadikan sampel. Adapun sampel dalam penelitian ini adalah laporan keuangan PT. Mustika Ratu Tbk dan PT. Martina Berto Tbk Rasio Profitabilitas 2021.

\section{E. DEFINISI OPERASI VARIABEL}

Kinerja keuangan merupakan gambaran kondisi keuangan perusahaan pada suatu periode tertentu baik dari aspek penghimpunan maupun penyaluran dana yang terjadi dalam perusahaan. Kinerja keuangan PT. Mustika Ratu Tbk dan PT. Martina Berto Tbk, di dalam penelitian ini menggunakan beberapa rasio-rasio di antaranya sebagai berikut:

1. Rasio Likuiditas ini menunjukkan kemampuan PT. Mustika Ratu Tbk dan PT. Martina Berto Tbk untuk memenuhi kewajiban atau utang jangka pendek yang diwakili:

a. Rasio Lancar (Current Ratio)

Current Ratio merupakan rasio untuk mengukur kemampuan suatu perusahaan untuk memenuhi kewajiban jangka pendeknya atau hutang yang segera jatuh tempo pada saat ditagih secara keseluruhan dengan aktiva lancar yang dimilikinya, yaitu dengan perbandingan antara jumlah aktiva lancar dengan hutang lancar.

b. Rasio cepat (Quick Ratio)

Rasio ini menunjukkan kemampuan perusahaan untuk membayar utang lancar (utang jangka pendek) yang harus segera dipenuhi dengan aktiva 
lancar yang tersedia dalam perusahaan tanpa memperhitungkan nilai persediaan (inventory).

c. Rasio Kas (Cash Ratio)

Rasio kas atau cash ratio merupakan alat yang digunakan untuk mengukur seberapa besar uang kas yang tersedia untuk membayar hutang. Jika rata-rata industri untuk cash ratio adalah 50\% maka keadaan perusahaan lebih baik dari perusahaan lain.

2. Rasio solvabilitas ini menggambarkan tentang seberapa besar kebutuhan PT. Mustika Ratu Tbk dan PT. Martina Berto Tbk yang dibiayai oleh utang yang diwakili:

a. Rasio Hutang Terhadap Total Aktiva (Debt to Assets Ratio/Debt Ratio)

Rasio ini menunjukkan seberapa besar dari keseluruhan aktiva perusahaan yang dibelanjai oleh hutang atau seberapa besar proporsi antara kewajiban yang dimiliki dengan kekayaan yang dimiliki.

b. Rasio Hutang Terhadap Ekuitas (Debt to Equity Ratio)

Rasio ini digunakan untuk menilai utang dengan ekuitas sehingga rasio ini berguna untuk mengetahui jumlah dana yang disediakan pinjaman (kreditor) dengan pemilik perusahaan.

c. Long-Term Debt To Equity Ratio

LTDtER merupakan rasio antara utang jangka panjang dengan modal sendiri dan hasil perhitungannya menunjukkan seberapa besar bagian dari setiap modal sendiri dijadikan jaminan untuk hutang jangka panjang.

d. Times Interest Earned

Rasio yang digunakan untuk mengetahui seberapa besar kemampuan perusahaan dalam memenuhi pembayaran bunga bagi kreditor.

3. Rasio profitabilitas digunakan untuk mengukur kemampuan PT. Mustika Ratu Tbk dan PT. Martina Berto Tbk untuk menghasilkan laba dari pendapatan yang berhubungan dengan penjualan, aset, dan ekuitas yang diwakili:

a. Net Profit Margin

Net Profit Margin merupakan rasio yang digunakan untuk mengukur margin laba bersih setelah bunga dan pajak atas penjualan neto pada suatu periode tertentu.

b. Gross Profit Margin

Rasio yang digunakan untuk menunjukkan laba yang relatif terhadap perusahaan dengan cara penjualan bersih dikurangi harga pokok penjualan.

c. Return On Asset (ROA)

Rasio yang digunakan untuk menunjukkan hasil atas jumlah aktiva yang digunakan dan mengukur tentang efektivitas manajemen dalam mengelola investasinya.

d. Hasil Pengembalian Ekuitas (Return On Equity/ ROE)

Hasil pengembalian ekuitas atau return on equity atau rentabilitas modal sendiri merupakan rasio untuk mengukur laba bersih (net income) sesudah pajak dengan modal sendiri, rata-rata standart industri untuk melihat 
ROE adalah 40\% (Kasmir: 2008). Semakin tinggi rasio ini maka semakin baik pula suatu perusahaan.

4. Rasio aktivitas

Rasio aktivitas merupakan rasio yang digunakan untuk mengukur efektivitas perusahaan dalam menggunakan aktiva yang dimilikinya. Atau dapat dikatakan rasio ini digunakan untuk mengukur tingkat efisiensi (efektivitas) pemanfaatan sumber daya perusahaan. Pengukuran rasio aktivitas terdiri dari:

a. Perputaran Persediaan (Inventory Turn Over)

Rasio ini digunakan untuk mengukur berapa kali dana yang ditanam dalam persediaan berputar dalam suatu periode. Perputaran sediaan merupakan rasio yang menunjukkan berapa kali jumlah barang sediaan diganti dalam satu tahun.

b. Fixed Assets Turn Over

Rasio ini merupakan rasio yang digunakan untuk mengukur berapa kali dana yang ditanamkan dalam aktiva tetap berputar dalam satu periode. Atau dengan kata lain, untuk mengukur apakah perusahaan sudah menggunakan kapasitas aktiva tetap sepenuhnya atau belum.

c. Perputaran Total Aktiva (Total Assets Turn Over)

Total asset turn over merupakan rasio yang digunakan untuk mengukur perputaran semua aktiva yang dimiliki perusahaan dan mengukur berapa jumlah penjualan yang diperoleh dari tiap rupiah aktiva.

\section{F. ANALISIS DATA}

Analisis data dilakukan dengan menggunakan pengujian deskriptif komparatif yang bertujuan untuk mengetahui kinerja keuangan pada perusahaan PT. Mustika Ratu Tbk dan PT. Martina Berto Tbk pada tahun 2021.

Analisis dalam penelitian ini menggunakan pendekatan kuantitatif yaitu mengklarifikasi, menghitung, dan menganalisis data. Pada tahap ini data diolah dan dimanfaatkan sedemikian rupa sehingga pada akhirnya berhasil menyimpulkan kebenaran-kebenaran yang dapat digunakan untuk menjawab permasalahan yang diajukan dalam penelitian.

Dalam penelitian ini akan dilakukan perhitungan terhadap rasio keuangan sebagai berikut:

1. Rasio Likuiditas

a. Rasio Lancar (Current Ratio)

b. Rasio Kas (Cash Ratio)

$$
\text { Current Ratio }=\frac{\text { Aktiva Lancar }}{\text { Hutang Lancar }} \times 100 \%
$$

$$
\text { Cash Ratio }=\frac{\text { Kas }}{\text { Hutang Lancar }} \times 100 \%
$$

c. Rasio Cepat (Quick Ratio)

$$
\text { Quick Ratio }=\frac{\text { Aktiva Lancar }- \text { Persediaan }}{\text { Hutang Lancar }} \times 100 \%
$$


2. Rasio Solvabilitas

a. Rasio Total Hutang Terhadap Aset (Debt to Asset Ratio)

$$
\text { Debt to Asset Ratio }=\frac{\text { Total Hutang }}{\text { Total Aset }} \times 100 \%
$$

b. Rasio Hutang Terhadap Ekuitas (Debt to Equity Ratio)

c. Long Term Debt to Equity Ratio

$$
\text { Debt to Equity Ratio }=\frac{\text { Total Hutang }}{\text { Ekuitas }} \times 100 \%
$$

$$
\text { Long Term Debt to Equity Ratio }=\frac{\text { Hutang Jangka Panjang }}{\text { Modal Sendiri }} \times 100 \%
$$

d. Times Interest Earned

$$
\text { Times Interest Earned }=\frac{\text { EBIT }}{\text { Biaya Bunga }} \times 100 \%
$$

3. Rasio Profitabilitas

a. Net Profit Margin

$$
\text { Net Profit Margin }=\frac{\text { Laba Setelah Bunga \& Pajak }}{\text { Penjualan }} \times 100 \%
$$

b. Gross Profit Margin

$$
\text { Gross Profit Margin }=\frac{\text { Laba Kotor }}{\text { Penjualan }} \times 100 \%
$$

c. Hasil Pengembalian Aset (Return On Asset / ROA)

$$
\text { Return On Asset }=\frac{\text { Laba Bersih }}{\text { Total Aset }} \times 100 \%
$$

d. Hasil Pengembalian Ekuitas (Return On Equity / ROE)

$$
\text { Return On Equity }=\frac{\text { Laba Bersih }}{\text { Ekuitas }} \times 100 \%
$$

4. Rasio Aktivitas

a. Inventory Turn Over

b. Fixed Asset Turn Over

$$
\text { Inventory Turn Over }=\frac{\text { Penjualan }}{\text { Persediaan }} \times 100 \%
$$

$$
\text { Fixed Asset Turn Over }=\frac{\text { Penjualan }}{\text { Aktiva Tetap }} \times 100 \%
$$

c. Total Asset Turn Over

$$
\text { Total Asset Turn Over }=\frac{\text { Penjualan }}{\text { Total Aktiva }} \times 100 \%
$$

\section{KESIMPULAN}


Berdasarkan hasil analisis data dari sejumlah data yang dihimpun, maka dapat ditarik kesimpulan sebagai berikut:

1. Rasio Likuiditas menunjukkan kemampuan PT. Mustika Ratu Tbk dan PT. Martina Berto Tbk untuk memenuhi kewajiban atau utang jangka pendek yang diwakili: Current Rasio, Cash Rasio, Quick Rasio.

2. Rasio solvabilitas menggambarkan tentang seberapa besar kebutuhan PT. Mustika Ratu Tbk dan PT. Martina Berto Tbk yang dibiayai oleh utang yang diwakili: Debt to Assets Rasio, Debt to Equity Rasio, Long Term Debt to Equity Rasio, Times Interest Earned.

3. Rasio profitabilitas digunakan untuk menilai kinerja keuangan perusahaan tersebut PT. Mustika Ratu Tbk dan PT. Martina Berto Tbk Dalam perhitungan rasio profitabilitas yaitu menggunakan rumus seperti: gross profit margin, net profit margin, return on assets dan return on equity. Kedua perusahaan mengalami penurunan keuntungan (inprofit), dalam perhitungan net profit margin, return on assets dan return on equity yang tidak memenuhi standar rata-rata industri, kecuali dalam perhitungan gross profit margin kedua perusahan di atas rata-rata industri. Tetapi, hasil perhitungan rata-rata dari kedua perusahaan PT. Martina Berto Tbk lebih baik dari pesaingnya yaitu PT. Mustika Ratu Tbk.

4. Rasio aktivitas mengukur seberapa efektif PT. Mustika Ratu Tbk dan PT. Martina Berto Tbk dalam memanfaatkan semua sumber daya yang ada dengan mewakili: Inventory Turn Over, Fixed Asset Turn Over dan Total Asset Turn Over.

\section{DAFTAR PUSTAKA}

Akbar, A., Diana, N., \& Afifudin, A. (2021). Analisis Kinerja Keuangan Perusahaan Sebelum dan Sesudah Penerapan E-Commerce (Studi Pada Perusahaan Sub Sector Retail Trade Dalam Index Saham Syariah Indonesia (ISSI) Di Bursa Efek Indonesia). Jurnal Ilmiah Riset Akuntansi, 10 (03).

Anggrenia, P. (2016). Analisis Rasio Keuangan untuk Menilai Kinerja Keuangan Perusahaan Kosmetik dan Barang Keperluan Rumah Tangga yang Terdaftar di BEI Periode 2009-2013. Jurnal Ilmiah Mahasiswa FEB, 3(2).

ANGGRIYANI BR GIRSANG, M. O. N. A. L. I. S. A. (2020). ANALISIS KINERJA KEUANGAN BERDASARKAN METODE VERTIKAL-HORIZONTAL PADA PERUSAHAAN KOSMETIK DAN BARANG KEPERLUAN RUMAH TANGGA YANG TERDAFTAR DI BURSA EFEK INDONESIA (Doctoral dissertation, Universitas Negeri Makassar).

Audina, V. N., \& Khotimah, H. (2021). Analisis Kinerja Keuangan Berdasarkan Rasio Likuiditas Pada PT. Jphan Konsultan Indonesia Tahun 2016-2018. Jurnal Penelitian Implementasi Akuntansi (JPIA), 2(1), 100-120.

Christian, P. Y., \& Prijati, P. (2015). Analisis Rasio Keuangan untuk Menilai Kinerja Keuangan pada Perusahaan Kosmetik di BEI. Jurnal Ilmu dan Riset Manajemen (JIRM), 4(10). 
Dambe, D. N., \& Sukmawati, H. (2021). ANALISIS KINERJA KEUANGAN PERUSAHAAN PADA HOTEL BANNE HARITAGE. JURNAL ULET (Utility, Earning and Tax), 5(1), 1-27.

Hakim, A. R., Daviya, M., \& Fauzi, N. (2013). Industri kosmetik dan manfaat bagi konsumen kosmetik di Indonesia. Majoring In Chemistry Faculty Of Math And Science Padang State University.

LESTARI, F. H. (2020). ANALISIS KINERJA KEUANGAN PT MARTINA BERTO Tbk. PERIODE 2016-2019.

Limbong, H., Ja'far, H., \& Raidani, R. (2021). ANALISIS LAPORAN KEUANGAN DENGAN PERHITUNGAN RASIO PROFITABILITAS, SOLVABILITAS, RENTABILITAS, LIKUIDITAS DAN AKTIVITAS UNTUK MENILAI KINERJA KEUANGAN PERUSAHAAN YANG TERDAFTAR DI BURSA EFEK INDONESIA (SUB SEKTOR KOSMETIK YANG TERDAFTAR DI BEI TAHUN 2015. BONANZA: Jurnal Ilmiah Ekonomi, Bisnis dan Keuangan, 1(1), 78-90.

Mu'arifin, H., \& Irawan, P. (2021). Analisis Kinerja Keuangan Perusahaan ditinjau dari Rentabilitas, Likuiditas dan Solvabilitas. Syntax Idea, 3(3), 533-545.

Mulyanti, D. (2017). Manajemen Keuangan Perusahaan. AKURAT| Jurnal Ilmiah Akuntansi FE UNIBBA, 8(2), 62-71.

Munda, N. N., Ilat, V., \& Runtu, T. (2021). ANALISIS KINERJA KEUANGAN PADA PERUSAHAAN BUMN SUBSEKTOR SEMEN YANG TERDAFTAR DI BURSA EFEK INDONESIA PERIODE 2017-2019. Jurnal EMBA: Jurnal Riset Ekonomi, Manajemen, Bisnis dan Akuntansi, 9(2).

Novianti, D. R. M., Mediaty, M., \& Usman, A. (2021). Kinerja Keuangan Terhadap Return Saham Perusahaan Kosmetik Yang Terdaftar Di Bursa Efek Indonesia. Accounting, Accountability, and Organization System (AAOS) Journal, 2(2), 179-193.

Shaknana, D. A. (2018). ANALISIS KINERJA KEUANGAN PADA DITINJAU DARI RASIO PROFITABILITAS TAHUN 2012-2016. INSTITUT AGAMA ISLAM NEGERI (IAIN) METRO 1439 H / 2018 M DITINJAU DARI RASIO PROFITABILITAS.

Syamsul, I. A. Analisis Kinerja Keuangan Perusahaan PT Asuransi Jasa Indonesia (Persero) dalam Memprediksi Pertumbuhan Laba Tahun 2019-2020.

Wahyuningroem, R. (n.d.). ANALISIS KINERJA KEUANGAN PADA PT. MUSTIKA RATU, Tbk.

WATI, E. F. R. (2017). ANALISIS KINERJA KEUANGAN PERUSAHAAN KOSMETIK YANG TERDAFTAR DI BEI (Doctoral dissertation, University of Muhammadiyah Malang).

Yusa, F. F. (1967). ANALISIS RASIO LIKUIDITAS DAN RASIO PROFITABILITAS DALAM RANGKA MENINGKATKAN KINERJA KEUANGAN (Kasus pada Perusahaan Kosmetik dan Barang Keperluan Rumah Tangga yang Terdaftar di 
Bursa Efek Indonesia). Angewandte Chemie International Edition, 6(11), 951-952., 3(2), 1-13. 